\title{
ANÁLISE COMPARATIVA DE TINTAS NATURAIS
}

\section{Camila Peres de Freitas ${ }^{1}$ Cassia Cristina de Lima Simões Magalhães ${ }^{2}$}

Resumo: - Este trabalho visa o desenvolvimento da tinta natural, que é um produto líquido, pastoso ou em pó, com propriedade de formar película após secagem ou cura, composto por uma mistura formada de pigmento, solvente, carga, aglutinante e aditivo, segundo as definições da norma ABNT NBR 15156. O desenvolvimento do trabalho ocorreu em laboratório tendo como foco a fabricação e comparação de duas tintas naturais com diferentes aglutinantes, Cola Acuminata e cera de abelha. As tintas foram fabricadas a base de terra com os respectivos aglutinantes e água. Após secagem e raspagem verifica-se que o aglutinante Cola Acuminata proporcionou melhor resultado em relação à cobertura e aderência. As análises e fabricações das tintas foram realizadas no laboratório de Química do Colégio UNIVAP - Unidade Villa Branca.

Palavras-chave: Tintas naturais; Aglutinantes; Cola acuminata; Cera de abelha; Qualidade.

\footnotetext{
${ }^{1}$ Técnico/Colégio Técnico UNIVAP - Villa Branca, Brasil. E-mail: camilaperes_99@hotmail.com

2 Técnico/Colégio Técnico UNIVAP - Villa Branca, Brasil. E-mail: cassia@univap.br.
} 